Przegląd Prawa Konstytucyjnego

-------ISSN 2082-1212--------

DOI 10.15804/ppk.2016.05.10

$-\mathrm{Nr} 5(33) / 2016$

Katarzyna Tomaszewska ${ }^{1}$

\title{
Udostępnianie informacji publicznej jako forma ochrony interesu prawnego jednostki w świetle regulacji dotyczących ogłaszania aktów normatywnych i niektórych innych aktów prawnych
}

Słowa kluczowe: dostęp, informacja publiczna, ogłaszanie, akty normatywne Keywords: access, public information, announcement, normative acts

\section{Streszczenie}

Dostęp do informacji publicznej stanowi warunek istnienia społeczeństwa obywatelskiego oraz przesłankę istnienia demokratycznego państwa prawa. Jako jedna $\mathrm{z}$ form kontroli społecznej dokonywanej przez podmioty zainteresowane informacyjnie, stanowi kategorię służącą ochronie interesu prawnego jednostki. Przedmiotem niniejszej kontroli jest należyte funkcjonowanie podmiotów władzy publicznej i realizowanie zadań służących zaspakajaniu zbiorowych potrzeb obywatelskich wynikających ze współżycia ludzi w społeczeństwie. Co istotne, w ramach szeroko rozumianego pojęcia informacji o sprawach publicznych, zawiera się również kategoria danych o istniejącym prawie, tj. treść jeszcze nieobowiązujących i obowiązujących uregulowań prawnych. A szczegółowe określenie podstaw prawnych, dopuszczalnych form i sposobów jej upublicznienia stanowi przedmiot niniejszego opracowania.

Autor jest adiunktem w Centrum Badań Problemów Prawnych i Ekonomicznych Komunikacji Elektronicznej Wydziału Prawa, Administracji i Ekonomii, Uniwersytetu Wrocławskiego. 


\title{
Summary
}

\author{
Making public information available as a form of protection \\ of the entities' legal interest in the light of the regulations concerning \\ the promulgation of normative acts and other selected legal acts
}

Access to public information is a prerequisite for the existence of civil society and the premise of the existence of a democratic state of law. As one of the forms of social control performed by entities interested in information, it constitutes a category serving to protect the legal interest of the individual. The subject of this control is the proper functioning of public authority entities and implementation of tasks aimed at satisfying the collective needs of citizens resulting from the coexistence of people in society. What is important in the context of widely understood notion of public affairs also includes the category of data on existing law, that is the content yet not in force and applicable legal regulations. A detailed indication of the legal basis, the permissible forms and methods of making information public is the subject of this paper.

W myśl art. 61 Konstytucji z 2 kwietnia 1997 r. „Obywatel ma prawo do uzyskiwania informacji o działalności organów władzy publicznej oraz osób pełniących funkcje publiczne...”2. Realizacja niniejszego uprawnienia, będącego publicznym prawem podmiotowym, sprowadza się do możliwości pozyskiwania danych, o których stanowi ustawodawca w treści art. 1 ust. 1 ustawy z 6 września 2001 r. o dostępie do informacji publicznej (dalej zw. u.d.i.p.) ${ }^{3}$. Najogólniej określając chodzi w tym wypadku o każdą informację o sprawach publicznych, a zatem o informację określającą zróżnicowane formy oraz sposoby działania podmiotów władzy publicznej. Zakres przedmiotowy tego rodzaju danych sprowadza się do „zdefiniowania" - do opisu struktury organów państwa, ich działalności oraz wyników aktywności podejmowanej na rzecz realizacji zadań o charakterze publicznym.

Szczegółowe i jednocześnie przykładowe rozwinięcie pojęcia informacji publicznej, znajduje się w katalogu przedstawionym przez ustawodawcę

\footnotetext{
Dz.U. 1997, Nr 197, poz. 483 ze zm.

3 Dz.U. 2015, poz. 2058.
} 
na gruncie art. 6 u.d.i.p. ${ }^{4}$ Co istotne z punktu widzenia prowadzonych rozważań, pośród całokształtu informacji uchodzących w świetle u.d.i.p. za dane publiczne, nie sposób odnaleźć wyróżnienia, które jednoznacznie wskazywałoby na publiczny charakter dokumentacji zawierającej w swej treści regulacje obowiązującego prawa. Ustawodawca w treści art. 6 ust. 1 pkt. 1 lit. b u.d.i.p. wskazuje jedynie na informacje o projektowaniu aktów normatywnych, dając tym samym wyraz ich publicznego charakteru ${ }^{5}$. Nie należy jednakże zapominać, że zawartość przywołanego powyżej uregulowania stanowi jedynie wyliczenie przykładowe. W żadnym razie nie wyczerpuje ono całokształtu znaczenia tak szerokiego pojęcia jakim jest informacja publicz$\mathrm{na}^{6}$.Treść obowiązującego prawa umiejscowionego w aktach normatywnych, w aktach prawnych jako rezultat (jako zwieńczenie działania) podmiotów władzy publicznej stanowi kategorię danych publicznych. Co więcej nie tylko zasługuje na upublicznienie, ale podlega obowiązkowemu udostępnieniu (przy użyciu zróżnicowanych form i sposobów działania). Za informację publiczną należy uznać treść dokumentów wytworzonych przez organy władzy publicznej, jak i również zawartość takiej dokumentacji, która pozostaje w ich dyspozycji w związku z realizacją zadań publicznych ${ }^{7}$. Będą to również dokumenty przygotowane $\mathrm{w}$ ramach procesu legislacyjnego ${ }^{8}$. Stanowią one

4 Wyrok NSA z 5 grudnia 2002 r., II SA/Wr 1600/02 (niepubl.), wyrok NSA z 13 października 2003 r., II SA/Ka 1706/03, http://www.orzeczenia-nsa.pl/wyrok/i-sa-ka-1706-03/ podatki_i_inne_swiadczenia_pieniezne_do_ktorych_maja_zastosowanie_przepisy_ordynacji_podatkowej/91c76e.html (27.10.2015), wyrok NSA z 2 lipca 2003 r., II SA 837/03, „Monitor Prawniczy” 2003, nr 17, s. 770, wyrok NSA z 30 października 2002 r., II SA 2037/02, http://orzeczenia.nsa.gov.pl/doc/38B03C4F3A (27.10.2015), zob. M. Jaśkowska, Dostęp do informacji publicznej $w$ świetle orzecznictwa Naczelnego Sądu Administracyjnego, Toruń 2002, s. 26; P. Szustakiewicz, Dostęp do informacji na podstawie ustawy o dostępie do informacji publicznej, [w:] Obywatelskie prawo do informacji, red. T. Gardocka, Warszawa 2008, s. 20-21. 5 M. Bernaczyk, M. Jabłoński, K. Wygoda, Biuletyn informacji Publicznej. Informatyzacja administracji publicznej, Wrocław 2005, s. 169-170; M. Bidziński, M. Chmaj, P. Szustakiewicz, Ustawa o dostępie do informacji publicznej, Warszawa 2010, s. 88; M. Jabłoński, K. Wygoda, Ustawa o dostępie do informacji publicznej. Komentarz, Wrocław 2002, s. 144.

6 P. Sitniewski, Ustawa o dostępie do informacji publicznej. Komentarz, Wrocław 2011, s. 16.

7 Wyrok WSA z 16 lipca 2008 r., II SA/Wa 721/08, http://orzeczenia.nsa.gov.pl/doc/3D15745F5F (26.10.2015).

8 „Dokumenty tworzone przez organy władzy publicznej podczas procesu legislacyjnego stanowią [...] informacje o sprawach publicznych, a [...] będąc rodzajem informacji dotyczącej 
wówczas formę uzewnętrznienia procesu kształtowania aktów o charakterze publicznoprawnym oraz przejmowania i załatwiania spraw przez odpowiednie organy władzy państwowej ${ }^{9}$. „Informacja o obowiązującym prawie jest informacją publiczną..." ${ }^{10}$. Będzie nią również odpowiedź organu, przygotowana w następstwie żądania jednostki zainteresowanej, którego treścią jest pozyskanie wykładni prawa ${ }^{11}$. Treść obowiązujących uregulowań prawnych w sposób oczywisty i niepodważalny stanowi element szeroko rozumianej informacji o sprawach publicznych. Jej zdobywanie opiera się na korzystaniu z powszechnego prawa do informacji. Inną natomiast kwestią jest fakt zróżnicowanego odniesienia prawnego, które występuje w kontekście realizacji procesu udostępniania danych dotyczących projektów aktów prawnych oraz aktów nieogłoszonych oraz w zakresie udostępniania aktów stanowiących fragment obowiązującego porządku prawnego. Jeżeli bowiem jednostka zainteresowana występuje z żądaniem udostępnienia jej informacji o treści obowiązującego prawa, w żadnym razie nie może opierać swojego roszczenia bezpośrednio na regulacjach u.d.i.p. ${ }^{12} \mathrm{~W}$ myśl bowiem art. 1 ust. 2 u.d.i.p. dostęp do zawartości aktów prawnych jest regulowany treścią odrębnego ustawodawstwa, a mianowicie ustawą z 20 lipca 2000 r. o ogłaszaniu ak-

sposobu stanowienia aktów publicznoprawnych i sposobu przyjmowania i załatwiania spraw, podlegają udostępnieniu w trybie u.d.i.p.": wyrok NSA z 18 listopada 2004 r., II SAB/Wa 166/04, ww.orzeczenia-nsa.pl/wyrok/ii-sab-wa-16604/sprawy_z_zakresu_informacji_publicznej_i_prawa_prasowego/1354161/2.html?q=\&_symbol=648\&_sad=Wojewódzki+Są$\mathrm{d}+$ Administracyjny+w+Warszawie\&_skarzony=Minister+Budownictwa\&_okres=2004_11 (26.10.2015).

9 Ibidem, I. Kamińska, M. Rozbicka-Ostrowska, Ustawa o dostępie do informacji publicznej. Komentarz, Warszawa 2012, s. 98.

10 P. Sitniewski, op.cit., s. 19.

11 „...Przepisy u.d.i.p. nie zawierają podstawy prawej do skutecznego żądania wykładni zapisów umowy zawartej przez organ samorządu terytorialnego...”, wyrok WSA z 11 września 2009 r., II SA/Ol 713/09, http://orzeczenia.nsa.gov.pl/doc/823F6DC32F (26.10.2015), wyrok WSA z 13 maja 2008 r., II SAB/Kr 7/08, http://orzeczenia.nsa.gov.pl/doc/099A526D73 (26.10.2015), „Ponieważ plan jest aktem prawa miejscowego, dlatego wykluczone jest interpretowanie jego zapisów w trybie ustawy o dostępie do informacji publicznej", - wyrok WSA z 1 lutego 2011 r., II SAB/Rz 50/10, http://orzeczenia.nsa.gov.pl/doc/662E66E0E1 (26.10.2015), postanowienie NSA z 24 stycznia 2006 r., I OSK 928/05, http://orzeczenia.nsa.gov.pl/doc/9CC1C79A14 (26.10.2015), P. Sitniewski, op.cit., s. 19.

12 Art. 1 ust. 2 u.d.i.p. 
tów normatywnych i niektórych innych aktów prawnych (dalej zw. u.o.a.n.) ${ }^{13}$. Podstaw zaś prawnych dla samego procesu ogłoszenia i jego ważności należy poszukiwać na gruncie art. 88 ustawy zasadniczej. Bez wątpienia stanowi on regulację lex specialis wobec uregulowania określonego treścią art. 61 ust. 1 Konstytucji RP. W myśl przywołanej regulacji: „Ogłoszenie jest warunkiem wejścia w życie ustawy, rozporządzenia oraz aktów prawa miejscowego. Zasady ogłaszania aktów normatywnych określa ustawa (u.o.a.n.). „[...] ogłoszenie jest czynnością określonego organu państwa, poprzez którą organ ten podaje informację o fakcie ustanowienia danych przepisów prawnych oraz tekst aktu normatywnego do wiadomości publicznej. W następstwie tego akt normatywny nabiera mocy obowiązującej (wchodzi w życie)"14.

Co jednak ważne, $\mathrm{z}$ punktu widzenia prowadzonych rozważań, odmienność występująca w zakresie podstawy regulacyjnej procesu udostępnienia aktów normatywnych i aktów prawnych, w żadnym razie nie deprecjonuje znaczenia kategorii dostępu do danych publicznych jako instytucji służącej ochronie interesu informacyjnego jednostki. Zasadniczym zatem celem prowadzonych rozważań jest wyróżnienie takich elementów, prawnych, które uwidaczniając się na gruncie uregulowań u.o.a.n., przesądzają o kwalifikowaniu procesu udostępniania (ogłaszania) informacji publicznej jako kategorii gwarantującej korzyści informacyjne po stronie zainteresowanego podmiotu.

Wprawdzie w żadnym państwie demokratycznym nie może dochodzić do sytuacji, w ramach której organy władzy publicznej stosują przymus wobec jednostki po to, aby przyjmowała one postawę aktywnego zaznajamiania się z treścią obowiązującego porządku prawnego ${ }^{15}$. Niemniej jednak istnienie fikcji powszechnej znajomości prawa, pozostaje w ścisłym związku

13 Dz.U. 2016, poz. 296; Nie dotyczy to projektów aktów prawnych i aktów nieogłoszonych, które podlegają upublicznieniu w trybie u.d.i.p. - wyrok NSA z 19 lutego 2002 r., II SA 3301/02, http://orzeczenia.nsa.gov.pl/doc/8B1D4AC7D3 (26.10.2015), G. Wierczyński, Pojęcie informacji publicznej $w$ świetle ustawy o dostępie do informacji publicznej, „Gdańskie Studia Prawnicze - Przegląd Orzecznictwa” 2005, nr 1-2, s. 55.

14 Postanowienie TKz 13 lutego 1991 r., sygn. akt. S 2/91, Z.U. OTKz 1991 r., poz. 30, wyrok TK z 7 lipca 2003 r., sygn. akt. SK 38/01, Z.U. OTK z 2003 r., nr 6A, poz. 61, wyrok TK z 21 stycznia 1997 r., sygn. akt. K 18/96, Z.U OTK z 1997 r., nr 1, poz. 2.

15 M. Groń, Elektroniczne dzienniki urzędowe. Wpływ wymagań technicznych dla dokumentów elektronicznych zawierajacych akty normatywne i inne akty prawne na ich treść, [w:] Informatyzacja postępowania sądowego i administracji publicznej, red. J. Gołaczyński, Warszawa 2010, s. 260. 
z zobowiązaniem organów administracji publicznej do gwarantowania dostępności do treści jeszcze nieobowiązujących, jak i również obowiązujących uregulowań prawnych ${ }^{16}$. Współcześnie nie budzi już żadnych zastrzeżeń stwierdzenie, w myśl którego gwarancja pozyskiwania informacji stanowiących „wiedzę” publiczną, jest nie tylko warunkiem istnienia społeczeństwa obywatelskiego, ale i również przesłanką urzeczywistniania reguł demokratycznego funkcjonowania podmiotów władzy publicznej ${ }^{17}$. Kategoria dostępu do informacji publicznej stanowi potwierdzenie dla występowania zjawiska liberalizacji stosunków społecznych, gospodarczych i politycznych ${ }^{18}$. Jest jednym z elementów kontroli społecznej, dokonywanej przez jednostki bezpośrednio lub pośrednio zainteresowane informacyjnie. Organy administracji publicznej (niezależnie od swojej właściwości, niezależnie od zajmowanego miejsca w strukturze organów państwa), podlegają obowiązkowi działania nie tylko na rzecz społeczeństwa, w jego imieniu i na jego rachunek, ale przede wszystkim za jego ogólną aprobatą i przy uzyskaniu jego pełnego poparcia ${ }^{19}$. Osiągnięcie niniejszego pociąga za sobą konieczność pełnego uświadomienia obywatelskiego w przedmiocie spraw publicznych ${ }^{20}$. Chodzi w tym wypadku zarówno o posiadanie wiedzy na temat faktycznych sposobów, form realizacji zadań, jak i informacji o wynikach działalności prowadzonej na rzecz ogółu obywateli. To implikuje zasadność twierdzenia, w myśl którego obywatele mogą oddziaływać na stan i funkcjonowanie państwa o tyle, o ile dysponują wiedzą o sprawowaniu władzy publicznej przez jego organy ${ }^{21}$. Świadomy udział obywateli w życiu społeczeństwa, którego są członkami, jak i kraju, w którym oni funkcjonują, zależy od stanu posiadania wiedzy o problemach państwa i jego narodu ${ }^{22}$. Możliwość pozyskania informacji publicz-

\footnotetext{
16 Ibidem.

17 W. Skrzydło, Konstytucja RP. Komentarz, Kraków 1998, s. 58.

18 T. Górzyńska, Prawo do informacji i zasada jawności administracyjnej, Kraków 1999, s. 11.

19 J. Naisbitt, Megatrendy, Warszawa, 1997, s. 197, podaję za T.R. Aleksandrowicz, Komentarz do ustawy o dostępie do informacji publicznej, Warszawa, 2008, s. 7.

20 P. Szustakiewicz, op.cit., s. 13, M. Jaśkowska, Dostęp do informacji publicznej. Zagadnienia wybrane (materiat na konferencjęsędziów, Popowo 14-16 października 2002), Warszawa 2002, s. 1 in. 21 T. Gardocka, Obywatelskie prawo do informacji, Warszawa 2008, s. 11.

22 M. Bidziński, M. Chmaj, P. Szustakiewicz, Ustawa o dostępie do informacji publicznej. Komentarz. Warszawa 2015, System informacji prawnej Legalis, http://sip.legalis.pl/document-view.seam?documentId=mjxw62zogiydkmjqge3tamq $(25.10 .2015)$.
} 
nych znajdujących się w otoczeniu jednostki, z jednej strony zwiększa (a przynajmniej powinna zwiększać) poczucie obywatelskiego zaufania dla organów i osób rządzących w państwie - z drugiej z kolei zobowiązuje organy państwa do podejmowania konkretnych działań o charakterze informacyjnym ${ }^{23}$. Ponadto w następstwie działań kontrolnych prowadzonych przez samych obywateli, proces udostępniania informacji stymuluje organy do podejmowania powszechnej debaty w przedmiocie najistotniejszych dla państwa spraw publicznych $^{24}$. Na tej płaszczyźnie słusznym wydaje się twierdzenie, że dostęp do informacji publicznej, jako kategoria wyrastająca z powszechnego prawa do informacji, stwarza jednostkom możliwość rzeczywistego partycypowania w życiu publicznym ${ }^{25}$. W swoim założeniu służy zapewnieniu jawności transparentności życia publicznego ${ }^{26}$. Daje tym samym wyraz posiadania przymiotu instytucji służącej ochronie interesu informacyjnego jednostki. Chodzi w tym wypadku o interes rozumiany jako zespół korzyści informacyjnych jednostek, gwarantowanych istnieniem zobowiązania po stronie organów władzy publicznej w przedmiocie powszechnego lub indywidulanego uświadamiania obywatelskiego.

Podstaw prawnych dla przypisywania kategorii dostępu do informacji publicznej statusu instytucji służącej ochronie interesu informacyjnego jednostki należy poszukiwać na gruncie uregulowań ogólnych (u.d.i.p.). W ramach całokształtu instrumentów uwidaczniających się na płaszczyźnie u.d.i.p., a przemawiających za istnieniem tego rodzaju ochrony można dokonać wyodrębnienia środków dwojakiego rodzaju:

- Grupy środków służących realizacji procesu udostępniania informacji publicznej;

- Grupy zasad określających sposób realizacji procesu udostępniania informacji publicznej.

„Udostępnianie informacji publicznej może przybierać wiele postaci i przyjąć należy, że dopuszczalne są wszystkie środki przekazu, a w gestii żądającego

\footnotetext{
23 K. Tarnacka, Prawo do informacji w polskim prawie konstytucyjnym, Warszawa 2009, s. 5. 24 Ibidem.

25 M. Zaremba, Prawo dostępu do informacji publicznej. Zagadnienia praktyczne, Warszawa 2009, s. 15, uchwała NSA z 11 kwietnia 2001 r., I OPS 1/05, http://orzeczenia.nsa.gov.pl/ doc/571022A55E (27.10.2015).
}

26 Ibidem. 
pozostaje decyzja, z jakich będzie on chciał skorzystać”27. I mimo iż ustawodawca nie odnosi się do niniejszych „środków” jako do instrumentów ochrony interesu jednostki, samo ich wyróżnienie i zasadność istnienia determinuje założenie o służebnej funkcji dostępu do informacji względem ochrony obywateli i ich interesów informacyjnych ${ }^{28}$. Z jednej bowiem strony są to elementy składające się na przedmiotowe pojęcie dostępu, z drugiej z kolei strony stanowią formy, przy użyciu których dochodzi lub może dojść do urzeczywistnienia procesu udostępnienia danych publicznych.

Z kolei w kontekście zasad determinujących sposób i przebieg procesu udostępniania informacji publicznej, należy zwrócić uwagę na zasadę powszechności (podmiotowej i przedmiotowej), zasadę bezpłatności, zasadę równego dostępu do informacji publicznej, zasadę sądowej kontroli udostępniania informacji publicznej oraz zasadę osobistej odpowiedzialności w związku z niezawinionym nieudostępnieniem określonych danych publicznych ${ }^{29}$. Ich istnienie gwarantuje dopuszczalność przyjęcia szerokiego katalogu podmiotów uprawnionych do występowania z roszczeniem informacyjnym, jak również wskazuje na istnienie szerokiego zakresu pojęcia informacji o sprawach publicznych. To również możliwość nieodpłatnego i równego dla każdego pozyskiwania informacji odnoszącej się do działalności podmiotów rządzących w państwie o ustroju demokratycznym. W ramach wyróżnionego katalogu zasad nie bez znaczenia pozostaje także kwestia dopuszczalności zaskarżenia przez wnioskodawcę faktu odmowy udostępnienia mu informacji, jak również faktu bezczynności organu w obliczu przedstawionego żądania informacyjnego. I w końcu występowanie katalogu prawnie określonych sankcji karnych (w postaci grzywny, ograniczenia wolności lub pozbawienia wolności) będących następstwem niewywiązania się z obowiązku informacyjnego, stanowi uzupełnienie założenia o postrzeganiu dostępu do informacji publicznej jako kategorii ochrony interesu prawnego jednostki.

Uwzględniając jednakże aspekt ochrony interesu jednostki w ramach procesu udostępniania treści regulacji prawnych koniecznym staje się przedsta-

27 Art. 10 ust. 1 u.d.i.p., M. Jabłoński, K. Wygoda, Dostęp do informacji i jego granice, Wrocław 2002, s. 170, podaję za P. Sitniewski, op.cit., s. 68.

28 Art. 3 ust. 1, art. 7 ust. 1, art. 10 oraz art. 11 u.d.i.p.

29 M. Bernaczyk, Obowiązek bezwnioskowego udostępniania informacji publicznej, Warszawa 2008, s. 121-122. 
wienie (quasi) odrębnego katalogu środków o charakterze informacyjnym w myśl uregulowań u.o.a.n. Posłużenie się w tym wypadku określeniem wskazującym na niepełną (niecałkowitą) odrębność przywołanego zbioru nie jest przypadkowa. Trzeba bowiem w tym wypadku zauważyć, że zakres instrumentów upubliczniania danych będących treścią obowiązującego porządku prawnego, nie pozostaje w całkowitym oderwaniu od zawartości regulacji u.d.i.p. Uwidacznia się to na skutek bezpośredniego odesłania „do zasad i trybu dostępu” regulowanego treścią uregulowań ogólnych, m.in. na płaszczyźnie art. 28 b ust. 1 pkt. 2 i ust. 1a pkt. 2 u.o.a.n.

W myśl art. 1 ust. 2, uregulowania u.d.i.p. nie naruszają przepisów innych ustaw, które przewidują odmienne zasady i tryb dostępu do danych będących informacjami publicznymi. W tym ujęciu chodzi o zespół instrumentów zawierających się w ogólnym rozumieniu pojęcia upubliczniania danych publicznych. Tego rodzaju proces uwidacznia się bowiem na płaszczyźnie u.o.a.n., mimo iż sama nomenklatura przywołanego ustawodawstwa sugeruje wąskie postrzeganie zagadnienia podawania informacji do publicznej wiadomości. Nie sposób jednak nie zauważyć, że mimo iż sam ustawodawca w tytule u.o.a.n. wskazuje wyłącznie na występowanie procesu ogłaszania, z punktu widzenia prowadzonych rozważań zasadnym wydaje się przyjęcie ogólnego określenia sprowadzającego się do upubliczniania przedmiotowych danych. Zabieg niniejszy wydaje się celowy, albowiem stwarza podstawy do wyodrębnienia dwojakiej kategorii zjawisk pozostających w ścisłym związku z zagadnieniem społecznego uświadamiania i ochrony interesu informacyjnego jednostki. Odnosząc się zatem do procesu upubliczniania jako do sposobu podawania do publicznej wiadomości treści już obowiązującego i jeszcze nieobowiązującego prawa (realizowanego z mocy prawa lub też na wniosek zainteresowanej jednostki) możliwym staje się wyróżnienie:

- Procesu ogłaszania aktów (jeszcze przed ich wejściem w życie);

- Procesu tworzenia możliwości zapoznawania się przez zainteresowanych z treścią aktów (już po ich wejściu w życie) - udostępnianie treści obowiązującego prawa.

Przywołując treść jednego z orzeczeń WSA: „ [...] za informację publiczną należy uznać informację o obowiązującym prawie”30. Co więcej w myśl art. 6

\footnotetext{
30 Wyrok WSA z 13 maja 2008 r., II SAB/Kr 7/08, http://orzeczenia.nsa.gov.pl/doc/099A526D73 (27.10.2015).
} 
ust. 1 pkt. 1 lit. a, ust. 1 pkt 2 lit. c, ust. 2 pkt 3 lit. a, b, c u.d.i.p. akty pochodzące od organów władzy publicznej, będące zwieńczeniem ich pracy, przed ich ogłoszeniem stanowią również informację publiczną. Akty organów władzy publicznej (ustawodawczej, wykonawczej) zarówno przed, jak i po wejściu w życie, posiadają identyczne znaczenie jako przejaw działania oraz wynik aktywności prowadzonej w obszarze tzw. spraw publicznych. Celowość ich istnienia z punktu widzenia prowadzonych rozważań pozostaje niezmienna. W sposób niezaprzeczalny mają one stanowić i stanowią płaszczyznę, przy użyciu której możliwym staje się dokonanie oceny działalności podmiotów władzy publicznej w bliższej, bądź dalszej perspektywie czasowej. Właściwym zatem wydaje się przyjęcie kwalifikacji, na mocy której wszystkie akty pochodzące od organów władzy publicznej stanowią informację o tzw. sprawach publicznych (w myśl art. 1 ust. 1 u.d.i.p.), sam zaś proces ogłoszenia jest szczególną formą udostępniania wiedzy publicznej. Uzasadnieniem dla niniejszego jest również aspekt funkcjonalny procesu upublicznienia. Proces ogłoszenia aktów pochodzących od podmiotów władzy publicznej wpisuje się bowiem w pojęcie demokratycznego państwa prawa. Należyte wypełnienie zobowiązania w przedmiocie ogłoszenia aktu normatywnego (aktu prawnego) służy urzeczywistnieniu konstytucyjnej zasady pogłębiania zaufania obywateli do państwa, do działających w jego imieniu organów oraz do istniejącego prawa ${ }^{31}$.

W myśl art. 1 ust. 1 regulacje u.o.a.n. określają zasady ogłaszania aktów normatywnych i niektórych innych aktów prawnych. W ramach niniejszego katalogu zasad, na pierwszy plan wysuwa się reguła obligatoryjności ogłaszania, reguła niezwłocznego ogłaszania, reguła nieodpłatności ogłoszenia oraz reguła elektronicznej publikacji. Analizując ich charakter oraz celowość ustanowienia należy wskazać, że posiadają one szczególne znaczenie w kontekście oceny założenia przyjętego na gruncie prowadzonych rozważań. Będąc bowiem płaszczyzną („otoczką”) realizacji omawianej formy upubliczniania danych publicznych, potwierdzają zasadność kwalifikowania kategorii dostępu do informacji jako instytucji służącej ochronie interesu informacyjnego jednostki. Dążąc do zinterpretowania procesu ogłoszenia jako jednej z form upubliczniania danych i, co więcej, jako szczególnej postaci dostępu do informacji publicznej, należy wskazać na dokonywanie czynności sprowadza-

31 M. Groń, op.cit., s. 260. 
jącej się do podawania do publicznej wiadomości urzędowego komunikatu ${ }^{32}$. Treść niniejszego komunikatu obejmuje zarówno informację o tym, że akt został ustanowiony, jak również zawartość przedmiotowego dokumentu stanowiącego wiedzę publiczną ${ }^{33}$.

Jak wskazuje ustawodawca ogłoszenie aktu normatywnego stanowi czynność materialno - techniczną o charakterze obowiązkowym (art. 2 u.o.a.n.). Tego rodzaju obligatoryjność działania sprowadza się do założenia, że tylko teksty upublicznione mogą i są kwalifikowane jako autentyczne oraz służą odzwierciedleniu faktycznej woli aktualnego prawodawcy ${ }^{34}$. Ogłoszenie jest warunkiem wejścia w życie danego aktu, chyba że przepis szczególny stanowi inaczej. Ustawa może wyłączyć obligatoryjność upubliczniania określonego aktu, wówczas gdy nie zawiera on w swej treści przepisów skierowanych na zewnątrz aparatu administracyjnego państwa (a jedynie zawiera regulacje wewnętrznie obowiązujące $)^{35}$. Należy zwrócić uwagę na występowanie bezpośredniości i pośredniości w procesie realizacji niniejszego zobowiązania. Pierwotna bowiem odpowiedzialność za wykonanie obowiązku upublicznienia aktu spoczywa na tym organie, który dany akt wydał (gdy jest kolegialny na jego przewodniczącym). To implikuje konieczność wystąpienia organu do właściwego podmiotu wydającego dziennik publikacyjny. Od tego momentu odpowiedzialność $\mathrm{z}$ tytułu ogłoszenia danego aktu, przechodzi bezpośrednio na organ zarządzający procesem wydawania publikatora urzędowego.

Odnosząc się z kolei do form realizacji omawianego procesu ogłoszenia należy zwrócić uwagę na treść art. 2a, art. 14 oraz art. 25 ust. 4 u.o.a.n. W ich świetle ustawodawca dokonuje ukształtowania środków, za pomocą których dochodzi lub może dochodzić do upublicznienia aktu normatywnego (aktu prawnego), a tym samym do realizacji ochrony interesu informacyjnego jednostki. Chodzi w tym wypadku:

\footnotetext{
32 G. Wierczyński, Komentarz do ustawy o ogłaszaniu aktów normatywnych i niektórych innych aktów prawnych, [w:] Redagowanie i ogłaszanie aktów normatywnych. Komentarz, red. G. Wierczyński, Oficyna 2009, http://lex.online.wolterskluwer.pl/WKPLOnline/index.rp$c$ ? \& from History=false\# content. rpc--ASK--nro=201336841\&wersja=-1\&localNroPart=0\&re $\mathrm{qId}=1446190806058 \_2036545611 \&$ class $=$ CONTENT $\&$ loc $=4 \&$ full $=1 \& \mathrm{hId}=8(25.10 .2015)$. 33 Ibidem.

34 A. Michalska, S. Wronkowska, Zasady tworzenia prawa, Poznań 1983, s. 337, J. Wróblewski, Zasady tworzenia prawa, Warszawa 1989, s. 130.

35 Art. 61 ust. 3 Konstytucji RP z 2 kwietnia 1997 r. oraz G. Wierczyński, Komentarz...
} 
- publikację w dzienniku urzędowym, o którym stanowi ustawodawca na gruncie art. 8 u.o.a.n;

- obwieszczenie lub ogłoszenie w inny zwyczajowo przyjęty sposób upubliczniania, przyjęty na danym terenie lub podanie do publicznej wiadomości za pomocą środków masowego przekazu.

W zakresie publikacji na szczególne podkreślenie zasługuje elektroniczna forma dokumentacji objętej procesem ogłoszenia oraz elektroniczny „charakter” środków, za pomocą których dochodzi do realizacji procesu udostępnienia danych ${ }^{36}$. Stosownie do treści ust. 2 art. 2a u.o.a.n. ogłoszenie aktu normatywnego polega na zamieszczeniu jego treści w jednym z dzienników urzędowych prowadzonych w postaci elektronicznej ${ }^{37}$. Ustawodawca dokonuje wyodrębnienia: Dziennika Ustaw Rzeczpospolitej Polskiej, Dziennika Urzędowego Rzeczpospolitej Polskiej „Monitor Polski”, dzienników urzędowych ministrów kierujących działami administracji rządowej, dzienników urzędowych urzędów centralnych i wojewódzkich dzienników urzędowych $^{38}$. Dla każdego dziennika urzędowego wydawanego przez prezesa Rady Ministrów, przez właściwych miejscowo wojewodów, przez ministrów resortowych oraz przez kierowników urzędów centralnych prowadzi się odrębną stronę internetową. Elektroniczny dziennik wydaje się z zachowaniem kolejności pozycji w danym roku kalendarzowym. Datą ogłoszenia aktu będącego dokumentem elektronicznym jest data jego zamieszczenia na właściwej witrynie internetowej. Dzień ogłoszenia podlega ujawnieniu poprzez zamieszczenie konkretnej daty w obrębie nagłówka strony.

Uwidaczniająca się na niniejszym gruncie „metoda” elektronicznej publikacji, stanowi przejaw procesu informatyzacji nakierowanego na podniesienie sprawności funkcjonowania podmiotów władzy publicznej oraz na rozwój

36 Rozporządzenie Prezesa Rady Ministrów z 27 grudnia 2011 r. w sprawie wymagań technicznych dla dokumentów elektronicznych zawierających akty normatywne i inne akty prawne, dzienników urzędowych wydawanych w postaci elektronicznej oraz środków komunikacji elektronicznej i informatycznych nośników danych (Dz.U. 2011, Nr 289, poz. 1699 ze zm.). 37 Art. 15 ust. 1 i ust. 2 u.o.a.n. oraz art. 3 pkt. 2 ustawy z 18 września 2001 r. o podpisie elektronicznym (Dz.U. 2013, poz. 262 ze zm.).

38 Art. 9, art. 10, art. 12 oraz w art. 14 u.o.a.n. W myśl ust. 4 art. 20 b u.o.a.n. jeden egzemplarz każdego z tych dzienników podlega przekazaniu: prezydentowi, marszałkowi Sejmu oraz Bibliotece Narodowej, art. 5 ust. 1 ustawy z 14 lipca 1983 r. o narodowym zasobie archiwalnym i archiwach (Dz.U. 2015, poz. 1446). 
społeczeństwa informacyjnego ${ }^{39}$. Sfera funkcjonowania podmiotów władzy publicznej podlega informatyzacji, rozszerzając tym samym elektroniczny dostęp do poszczególnych agend państwa ${ }^{40}$. Informacja stanowi podstawę nowoczesnej gospodarki i nowoczesnego społeczeństwa ${ }^{41}$. Opiera się ona na szerokich zasobach informacyjnych i nowoczesnych technologiach gromadzenia danych i ich przekazywania. „, [...] Tylko Internet jest w stanie zapewnić każdemu, niezależnie od tego gdzie on się znajduje, dostęp do prawa, w tym samym czasie: paradoksalnie obecnie Internet jest bardziej dostępny niż papier”42. W tych realiach dostęp do określonych informacji staje się łatwiejszy, a sam ich przepływ (w tym publiczny przekaz) cechuje się szybkością docierania wiedzy do świadomości jednostek zainteresowanych. Dla rzeczywistych beneficjentów, podstawowe znaczenie posiada to, czy są oni w stanie uzyskać oczekiwaną informację w sposób łatwy i szybki, bez konieczności ponoszenia dodatkowych nakładów finansowych ${ }^{43}$. Nie jest to jednak jedyny pozytywny element będący następstwem „elektronicznego procesu” ogłaszania aktów normatywnych i niektórych innych aktów prawnych. Słusznie zauważa M. Groń, że dokument elektroniczny zawsze jest „bardziej” dostępny niż dokument występujący w formie papierowej ${ }^{44}$. Poszerza on bowiem możliwości komunikacyjne (samo pozyskanie danych) i informacyjne (zapoznanie się $\mathrm{z}$ treścią pozyskanych danych $)^{45}$. Kreuje podstawy do sprawnego przeszukiwania treści, do filtrowania, kopiowania, czy też przenoszenia zawartości określonej dokumentacji z jednego miejsca do drugiego lub kolejnego ${ }^{46}$.

Kontynuując rozważania nie sposób pominąć uregulowania określonego treścią art. $14 \mathrm{w}$ związku z art. 25 u.o.a.n. W myśl przywołanej regulacji, przepisy

\footnotetext{
39 T. Burczyński, Elektroniczna wymiana informacji $w$ administracji publicznej, Wrocław 2011, s. 15.

40 D. Szostek, e-Administracja. Prawne zagadnienia informatyzacji, Wrocław 2009, s. 12.

${ }_{41}$ T. Burczyński, op.cit., s. 15.

42 J.P. Bolufer, Organisation and role sof offical journals, http://circa.europa.eu/irc/opoce/ojf/ info/data/prod/html/act113en.htm, - podaję za M. Groń, op.cit., s. 265.

43 M. Bernaczyk, Udostępnianie informacji publicznych w postaci elektronicznej w orzecznictwie sądów administracyjnych, [w:] Informatyzacja postępowania sądowego i administracji publicznej, red. J. Gołaczyński, Warszawa 2010, s. 249-250.

44 M. Groń, op.cit., s. 265.

45 Ibidem.

46 M. Groń, op.cit., s. 265.
} 
porządkowe ogłasza się w formie obwieszczenia, a także w inny sposób zwyczajowo przyjęty na danym terytorium lub w środkach masowego przekazu (lokalne radio lub lokalna telewizja). Redakcje, o których mowa na gruncie art. 7 ust. 1 pkt 8 ustawy z 26 stycznia 1984 r. - Prawo prasowe ${ }^{47}$, dokonują opublikowania treści przepisów porządkowych lub opublikowania ich uzgodnionych interpretacji w sposób bezpłatny i gwarantujący ich szeroką dostępność oraz aktualność. Na tym etapie koniecznym wydaje się wskazanie, że obwieszczenie i inne zwyczajowo przyjęte sposoby upubliczniania informacji, nie tylko nie posiadają znaczenia uzupełniającego w procesie ogłaszania niniejszej kategorii aktów prawa miejscowego, ale stanowią podstawową formę upubliczniania przepisów porządkowych. To jednak w żadnym razie nie eliminuje, nie ogranicza obowiązku ich ogłoszenia we właściwym miejscowo wojewódzkim dzienniku urzędowym.

Ponadto warto także zwrócić uwagę na odmienność uwidaczniającą się w kontekście dopuszczalności ustalania daty ogłoszenia przepisu porządkowego. Nie jest nią bowiem data elektronicznego upublicznienia na stronie internetowej prowadzonej przez właściwego wojewodę, ale data uwidoczniona w treści samego obwieszczenia. Co więcej musi ona być zgodna z faktyczną datą podawania „informacji” do publicznej wiadomości. Analizując celowość utrzymania przez ustawodawcę niejako „papierowej” (choć nie wyłącznie) formy ogłaszania przepisów porządkowych, warto zwrócić uwagę na aspekt pozostający w ścisłym związku z typologią niniejszej „dokumentacji” jako najbliższej członkom danej społeczności lokalnej. Zachowanie i stosowanie formy obwieszczenia lub innych zwyczajowo przyjętych form upubliczniania treści przepisów porządkowych pozwala zachować jedność występującej tradycji i posiadanych przez jednostki nawyków $\mathrm{w}$ przedmiocie zaznajamiania się z treścią informacji powszechnych i publicznych $^{48}$. To do tego rodzaju form ogłaszania mieszkańcy gmin wiejskich są przyzwyczajeni, a miejsca powszechnego zamieszczania ogłoszeń publicznych, są od lat przez nich znane i najczęściej odwiedzane ${ }^{49}$. W tym zatem znaczeniu wyróżnione formy ogłaszania jawią się jako najefektywniejszy sposób upubliczniania prawa, a tym samym i środek ochrony interesu informacyjnego jednostki ${ }^{50}$.

\footnotetext{
47 Dz.U. 1984, Nr 5, poz. 24 ze zm.

48 P. Sitniewski, op.cit., s. 173.

49 Ibidem.

50 Stosownie do treści art. 3 u.o.a.n. akty normatywne ogłasza się niezwłocznie; wyrok WSA z 8 grudnia 2004 r. w Bydgoszczy, II SA/Bd 913/04 (niepubl.).
} 
Przechodząc z kolei do tzw. właściwego procesu udostępnienia aktów normatywnych (aktów prawnych), możliwym i celowym staje się wyodrębnienie następujących środków publicznego i indywidualnego przekazu:

- Możliwości bezpośredniego wglądu do elektronicznej zawartości dzienników urzędowych i ich zbiorów znajdujących się na stronach internetowych tzw. organów wydających lub na stronach internetowych Rządowego Centrum Legislacji ${ }^{51}$;

- Możliwości pobierania elektronicznego dziennika lub zawartego w jego treści aktu normatywnego lub aktu prawnego występującego w formie elektronicznej;

- Możliwości powszechnego wglądu do treści elektronicznego dziennika urzędowego i jego zawartości w godzinach pracy urzędów obsługujących te organy, w miejscu do tego przeznaczonym i powszechnie dostępnym, za pomocą urządzeń posiadających dostęp do Internetu;

- Możliwości pozyskania informacji (treści obowiązującego prawa i ich publikatorów) za pomocą środków komunikacji elektronicznej i informatycznych nośników danych, o których mowa w treści art. 3 pkt. 1 oraz art. 3 pkt. 4 ustawy z 17 lutego 2005 r. o informatyzacji działalności podmiotów realizujących zadania publiczne (dalej zw. u.o.i.d.p. $)^{52}$, w sposób adekwatny do wniosku zainteresowanego oraz na zasadach i w trybie określonym treścią u.d.i.p.;

- Możliwości wglądu i pobierania elektronicznego zbioru aktów prawa miejscowego, również w godzinach pracy urzędów obsługujących właściwe organy, w miejscu do tego przeznaczonym i powszechnie dostępnym za pomocą urządzeń posiadających dostęp do Internetu;

- Możliwości pozyskania (wglądu i pobierania) zbioru dziennika urzędowego UE, również w godzinach pracy urzędów obsługujących te organy, w miejscu do tego przeznaczonym i powszechnie dostępnym za pomocą urządzeń posiadających dostęp do Internetu;

- Możliwości uzyskania papierowego wydruku aktu normatywnego

51 W zakresie udostępniania dzienników z aktami prawymi, które zawierają informacje niejawne stosuje się przepisy ustawy z 5 sierpnia 2010 r. o ochronie informacji niejawnych (Dz.U. 2010, Nr 182, poz. 1228 ze zm.).

52 Dz.U. 2014, poz. 1114, art. 2 pkt. 5 ustawy z 18 lipca 2002 r. o świadczeniu usług drogą elektroniczną (Dz.U. 2013, poz. 1422). 
lub aktu prawnego znajdującego się w treści określonego dziennika urzędowego.

Istnienie przedstawionego katalogu pozostaje w ścisłym związku z założeniem, w myśl którego właściwe organy władzy publicznej poza ogłoszeniem aktów normatywnych i niektórych innych aktów prawnych, są zobowiązane również do stworzenia jednostce takich warunków, na płaszczyźnie to których dzienniki publikacyjne będą jak najbardziej dostępne, a środki realizacji procesu udostępnienia ich zawartości będą stanowiły sprawne instrumenty ochrony jej interesu informacyjnego ${ }^{53}$. W ramach przedstawionej powyżej egzemplifikacji dostrzegalne są zarówno elementy o charakterze szczególnym (właściwe tylko i wyłącznie dla procesu upubliczniania aktów normatywnych i aktów prawnych), jak również poprzez odesłanie do uregulowań u.d.i.p. elementy typowe dla procesu udostępniania tzw. danych publicznych w ich ujęciu ogólnym i powszechnym. Ponadto nie sposób nie zauważyć, że na płaszczyźnie środków realizacji procesu upublicznienia treści obowiązującego prawa, uwidacznia się zasada nieodpłatności działania podmiotów władzy publicznej. Fakt jej występowania bezsprzecznie stanowi potwierdzenie dla założenia o ochronie interesu informacyjnego jednostki. Co jednak ważne podobnie jak na gruncie uregulowań u.d.i.p. ustawodawca i w tym zakresie przewiduje wyjątki od jej obowiązywania. Chodzi w tym wypadku o treść uregulowania zawartego w art. 28 a u.o.a.n. Jednostka zainteresowana uzyskaniem papierowego wydruku treści dziennika urzędowego (aktu normatywnego) zobowiązana jest bowiem do uiszczenia stosownej opłaty tytułem poniesienia dodatkowych nakładów finansowych związanych z przygotowaniem wnioskowanej dokumentacji ${ }^{54}$.

Reasumując przedstawione rozważania należy wskazać, że obligatoryjność upubliczniania treści uregulowań prawnych (niezależnie od ich statusu obowiązywania), stanowi jednoznaczne potwierdzenie dla założenia o realizacji ochrony interesu informacyjnego jednostki. Świadczy o tym możliwość wyodrębnienia zróżnicowanych form i sposobów realizacji zobowiązania informacyjnego na gruncie uregulowań u.o.a.n. Analizując ich charakter, jak również uwzględniając posiadane właściwości należy wskazać, że zawiera-

53 M. Groń, op.cit., s. 260.

54 Art. 28 a zd. 2 u.o.a.n. 
ją się one w ogólnym postrzeganiu procesu ogłoszenia oraz procesu udostępniania aktów normatywnych. Na tej płaszczyźnie słusznym wydaje się przyjęcie stanowiska, w myśl którego zawsze mniej korzystna jest sytuacja osoby, która mając dokonać oceny, a następnie na jej podstawie podjąć określoną decyzję, dysponuje mniejszym zasobem informacji, od położenia innego podmiotu, który w identycznych warunkach i przy użyciu tych samych środków rozporządza większą ilością danych (niezależnie od ich rodzaju) ${ }^{55}$. Wprawdzie świadomość obowiązujących uregulowań prawnych nie daje żadnej pewności, że będą one powszechnie znane, akceptowane, a tym bardziej przestrzegane przez ich adresatów, niemniej jednak poszerza szanse ich efektywności, ograniczając tym samym ilość nadużyć i przewinień, które mogłyby stanowić pośredni rezultat nieznajomości istniejącego prawa ${ }^{56}$. Sama zaś wiedza o regulacjach prawnych (o ich treści, o ich stanowieniu) kreuje podstawy dla dokonania oceny kompetencji podmiotów „znajdujących się u władzy", w przedmiocie tworzenia porządku prawnego obowiązującego w danym miejscu i w danym czasie.

\section{Literatura}

Aleksandrowicz T.R., Komentarz do ustawy o dostępie do informacji publicznej, Warszawa 2008.

Bernaczyk M., Jabłoński M., Wygoda K., Biuletyn informacji Publicznej. Informatyzacja administracji publicznej, Wrocław 2005.

Bernaczyk M., Obowiązek bezwnioskowego udostępniania informacji publicznej, Warszawa 2008.

Bidziński M., Chmaj, M., Szustakiewicz P., Ustawa o dostępie do informacji publicznej, Warszawa 2010.

Bidziński M., Chmaj M., Szustakiewicz P., Ustawa o dostępie do informacji publicznej. Komentarz, Warszawa 2015.

Burczyński T., Elektroniczna wymiana informacji w administracji publicznej, Wrocław 2011. Gardocka T., Obywatelskie prawo do informacji, Warszawa 2008.

55 F. Studnicki, Przepływ wiadomości o normach prawnych, „Zeszyty naukowe Uniwersytetu Jagiellońskiego”, Prace prawnicze, 1965, z.32, s. 51 - podaję za M. Groń, op.cit., s. 264. 56 Ibidem. 
Gołaczyński J., Informatyzacja postępowania sądowego i administracji publicznej, Warszawa 2010.

Górzyńska T., Prawo do informacji i zasada jawności administracyjnej, Zakamycze 1999. Jabłoński M., Wygoda K., Ustawa o dostępie do informacji publicznej. Komentarz, Wrocław 2002.

Jabłoński M., Wygoda K., Dostęp do informacji i jego granice, Wrocław 2002.

Jaśkowska M., Dostęp do informacji publicznej w świetle orzecznictwa Naczelnego Sąu Administracyjnego, Toruń 2002.

Jaśkowska M., Dostęp do informacji publicznej. Zagadnienia wybrane (materiał na konferencję sędziów, Popowo 14 -16 października 2002), Warszawa 2002.

Kamińska I., Rozbicka-Ostrowska M., Ustawa o dostępie do informacji publicznej. Komentarz, Warszawa 2012

Michalska A., Wronkowska S., Zasady tworzenia prawa, Poznań 1983.

Sitniewski P., Ustawa o dostępie do informacji publicznej. Komentarz, Wrocław 2011.

Skrzydło W., Konstytucja RP. Komentarz, Kraków 1998.

Studnicki F., Przepływ wiadomości o normach prawnych, „Zeszyty naukowe Uniwersytetu Jagiellońskiego", Prace prawnicze, 1965, z. 32.

Szostek D., e-Administracja. Prawne zagadnienia informatyzacji, Wrocław 2009.

Tarnacka K., Prawo do informacji w polskim prawie konstytucyjnym, Warszawa 2009.

Wierczyński G., Pojęcie informacji publicznej w świetle ustawy o dostępie do informacji publicznej, „Gdańskie Studia Prawnicze - Przegląd Orzecznictwa” 2005, nr 1-2.

Wierczyński G., Redagowanie i ogłaszanie aktów normatywnych. Komentarz, Oficyna 2009.

Wróblewski J., Zasady tworzenia prawa, Warszawa 1989.

Zaremba M., Prawo dostępu do informacji publicznej. Zagadnienia praktyczne, Warszawa 2009. 